\title{
Fiji's 1999 general elections: outcomes and prospects
}

\author{
Satendra Prasad
}

\section{Introduction}

For Fiji, the May 1999 general elections have been exceptionally significant and historic. ${ }^{1}$ They were the first elections held under the provisions of the 1997 constitutional settlement, which was a product of unprecedented negotiation and compromise between the main political actors in Fiji (Ghai, this volume). As a consequence, the outcome of the elections provides some basis for interpreting the validity of certain key assumptions underpinning the 1997 Constitution. At the same time, the outcome of the 1999 elections can also provide some indication of the commitment of different political actors to the 1997 constitutional settlement, in part because the 1999 general elections were the first since 1987 in which there was a real possibility of removing the dominant political party-in this case, the Soqosogo $\mathrm{Ni}$ Vakavulewa Ni Taukei (SVT)—from power. Finally, the 1999 general elections were held in an environment where successive governments had, since 1986, made strong commitments to pursuing policies of structural adjustment and trade liberalisation (Sepehri and AkramLodhi, this volume). The outcome of the 1999 elections can provide some guide as to the extent to which these commitments have been accepted by the peoples of Fiji, which will undoubtedly affect Fiji's political and economic prospects as it negotiates global economic challenges.

These aspects of the 1999 general elections have a bearing on some of the issues raised in other contributions to this collection. As a consequence, Fiji's 1999 general elections may help us assess how 
some of the issues raised in this collection are likely to play themselves out over the next decade. In part, this is because a reflection on the outcome of the elections and an evaluation of some of the key voting trends that were witnessed may provide clues which facilitate an understanding of how dominant structures of ethnicity and class may effect the developmental prospects of this small, vulnerable and globalising economy. It is in this light that this chapter discusses the outcome of the 1999 general elections in Fiji. Following this introduction, the next section examines how some key features of the 1997 Constitution may have affected the 1999 elections in ways other than those of electoral processes. The chapter then discusses the main political parties that engaged in the 1999 election and examines the strategies of the parties in light of the voting system that was used. The process that led to the formation of the Cabinet is also examined. In the context of these outcomes the chapter critically assesses the success of the alternative vote (AV) system, particularly in terms of its capacity to foster a more multiethnic politics in Fiji. The chapter concludes by examining whether the new Government will be able to respond to the challenge of the future in light of its constitutional obligations.

\section{The 1997 Constitution and the 1999 general elections}

During the review of the 1990 Constitution much of the debate on the set of possible constitutional arrangements capable of dealing with ethnic divisions in Fiji came to revolve around three principal issues. The first issue was whether there should be a guarantee of indigenous Fijian advantage in the allocation of parliamentary seats, so as to allay any possible fears about the dilution of indigenous Fijian interests. The second issue followed: what was an acceptable ratio between ethnically reserved, 'communal' parliamentary seats and nonreserved, 'open' parliamentary seats? The third issue tied the other two issues together: what was to be the electoral process under which members of parliament were to be elected to open and reserved seats? As will be seen, these issues had an impact on the particular strategies used by political parties during the course of the 1999 elections, and in so doing helped shape the outcome of the elections.

The Fiji Constitution Review Commission (FCRC) argued that particularly but not exclusively in light of the events of the late 1980s and early 1990s it was necessary to move Fiji gradually but decisively 
away from the 'politics of race'. To that end, the FCRC recommended that the predominant feature of the electoral system which was to emerge out of the constitutional review should be that parliamentary seats would be 'open': that is, all voters residing in a particular constituency would be free to contest and vote in an election. The FCRC therefore proposed that Fiji's parliament have 12 seats reserved for indigenous Fijians; 10 seats reserved for Indo-Fijians; 2 seats reserved for 'general electors', that is to say those voters who were neither indigenous Fijian nor Indo-Fijian; and 1 seat reserved for the Rotuman community. Thus, the FCRC recommended that 25 parliamentary seats be reserved on the basis of ethnicity. Concurrently, the FCRC recommended that there be 45 open seats. The FCRC argued that the proposed ratio between open and reserved seats would ensure that political parties contesting elections would mainly focus their attention and hence their political strategies on winning the open seats, and indeed the FCRC's recommendations represented a major window of opportunity for Fiji to reduce the ethnic orientation of its politics.

However, the Joint Parliamentary Select Committee (JPSC), which was charged with developing a parliamentary consensus on the constitutional amendments to emerge out of the review process, rejected this ratio. Indeed, the JPSC favoured a reversal of the ratio of open to reserved parliamentary seats. The JPSC thus proposed that 23 parliamentary seats be reserved for indigenous Fijians, 19 parliamentary seats be reserved for Indo-Fijians, 3 parliamentary seats be reserved for general electors, and 1 parliamentary seat be reserved for the Rotuman community. The JPSC further proposed that in addition to 46 reserved parliamentary seats there be 25 open parliamentary seats. The reversal in the ratio of open parliamentary seats to reserved parliamentary seats clearly favoured those political parties which were organised on the basis of ethnicity, and thus apparently compromised an explicit objective of the FCRC: namely, movement away from the 'politics of race'. In this light, it is perhaps not surprising that the main political parties in the JPSC were the SVT and the National Federation Party (NFP). Both are almost exclusively organised on the basis of ethnicity, with the SVT having been a key political actor amongst the indigenous Fijian community during the 1990s and the NFP having been a key political actor amongst the IndoFijian community since the 1960s. At the same time, as will be seen the 
domination of reserved parliamentary seats in the allocation of total parliamentary seats had a critically important yet possibly unexpected impact on the strategies employed by the political parties during the 1999 general elections.

Despite an allocation of open to reserved parliamentary seats which favoured political parties organised on the basis of ethnicity, the 1997 Constitution did introduce an additional mechanism which had as its explicit rationale the objective of reducing the role of ethnicity in Fiji's politics. This mechanism is power sharing. Under the 1997 Constitution, all parties having 10 per cent or more of the membership of parliament are guaranteed representation in the executive arm of govemment, the cabinet. Membership in cabinet was to be in proportion to the overall number of parliamentary seats held. This provision of the 1997 Constitution, which represented a major departure away from the approach espoused by the FCRC, was designed to ensure that political parties would co-operate after the general elections.

The 1999 general elections were conducted using an AV system. Under Fiji's AV system, voters must rank their preferences amongst the candidates for both open and reserved parliamentary seats. If no candidate secures an absolute majority of the first preferences expressed by the voters, those candidates at bottom of the poll are eliminated and the second preferences of those voters who voted for candidates at the bottom of the poll are counted. If no candidate secures an absolute majority of first and second preferences, the process is repeated until an absolute majority is secured for one candidate.

Despite its apparent complexity, and the concomitant possibility that voters would not really understand the electoral system that they were using, the AV system was nevertheless adopted in order to overcome the excessively ethnic orientation of the elections which had been conducted under both the 1990 and the 1970 Constitutions. Granted, the processes at work in mobilising votes under the AV system for reserved and open seats were likely to be different. In reserved seats, it was to be expected that political mobilisation would follow those processes witnessed in elections under the 1990 and 1970 Constitutions; namely, the main parties would emphasise ethnic interests and make appeals to 'ethnic unity'. However, for open seats it was hoped that the AV system would facilitate the deployment of less ethnically exclusive strategies by giving clear incentives to political parties in the pursuit of power to seek out votes from a multiplicity of 
ethnic communities (Ghai, this volume). Indeed, the FCRC envisaged that the introduction of the AV system would in the long term promote the emergence and consolidation of multiethnic parties, while in the short term the introduction of the AV system would facilitate the emergence of cooperative arrangements and alliances between ethnically based parties (FCRC 1996). Thus, the promotion of interethnic cooperation was an explicit aim of the AV system. Through the promotion of inter-ethnic cooperation, the electoral system was to have a key role in moving Fiji gradually but decisively away from the 'politics of race' and towards an underlying goal of the 1997 Constitution, namely the promotion of racial harmony and national unity (Prasad 1999). Thus, while the choice of the voting system clearly has had an impact on the outcome of the 1997 elections, assessing the overall consequences of the introduction of the $\mathrm{AV}$ system is more complex, in large part because the assumptions that have underpinned its choice as a method of electing parliamentary representatives have had a significant effect on the final results of the election.

Clearly, the provisions of the 1997 Constitution have had a deeper effect on the political processes underpinning the1999 general elections than a first glance at its stipulated electoral procedures might appear to indicate. In particular, the ratio of open to reserved parliamentary seats, the statutes governing the formation of the executive arm of government, and the electoral system have effected the outcome. This effect however has not been linear; rather, it has been refracted through the strategies of the political parties that contested the election. Party strategies and the outcome of the 1999 general election is the subject of the next section.

\section{The results of the 1999 general elections}

\section{The parties}

The main parties that contested the 1999 general elections were the

1. Soqosoqo Ni Vakavulewa Ni Taukei (SVT). The SVT was the dominant political party to emerge after the coups of 1987. Its support was derived almost exclusively from the indigenous Fijian community, and it formed the Government after both the 1992 and 1994 general elections. The SVT was the predominant indigenous Fijian party engaged in the 
constitutional review process. It was also the central indigenous Fijian party in the JPSC, and as such took a large measure of responsibility for negotiating the new constitution.

2. National Federation Party (NFP). The NFP was the oldest of the parties that contested the 1999 elections, having been formed in the 1960s during the agitation for independence. Since independence the NFP had remained in opposition, deriving its support largely from the Indo-Fijian community. It became an exclusively Indo-Fijian party after the 1992 general elections, when it emerged as the largest Indo-Fijian political grouping. After the SVT, the NFP was the key player in the JPSC, and as such it also took a large measure of the responsibility for the new constitution.

3. Fijian Association Party (FAP). The FAP emerged as a parliamentary breakaway from the SVT after the 1992 elections, when the SVT's Sitiveni Rabuka, leader of the 1987 coups, and the late Josefata Kamikamica, Finance Minister under the military-backed Interim Government and eventual founder of the FAP, clashed over who should become prime minister. The support base of the FAP is largely concentrated among indigenous Fijians from the central and southeastern provinces on Viti Levu.

4. Fiji Labour Party (FLP). The FLP party was created in 1985, with strong support from the Fiji Trades Union Congress. It won the 1987 general elections in coalition with the NFP, under the leadership of the late Timoci Bavadra. The victory of the FLP-NFP coalition in 1987 led to two military coups. The coalition was ruptured by the 1992 elections. In both the 1992 and 1994 elections the FLP won a minority of the seats reserved for the Indo-Fijian community. Nonetheless, despite drawing a large measure of support from within the IndoFijian community, of all the political parties only the FLP has maintained some semblance of cross-community support and multiethnic orientation since the 1987 coups.

5. Veitokani Ni Lewenivanua Vakaristo (VLV). This exclusively indigenous Fijian party evolved during the lead up to the 1999 general elections. It draws its support and enthusiasm from a powerful segment within the Methodist Church. 
6. Party of National Unity (PANU). The PANU was in some senses a successor to the defunct All National Congress (ANC). It emerged in the run up to the 1999 elections. Like the ANC, the PANU draws its support mainly from indigenous Fijians in western Viti Levu.

7. Nationalist Vanua Takolavo Party (NVTLP). The NVTLP is the successor to the Fijian Nationalist Party. Like its predecessor, the NVTLP has developed a strongly nationalistic, if not indeed openly chauvinistic, indigenous Fijian platform, which is explicit in its anti-Indo-Fijian agenda. The NVTLP finds its main support in the central and southern provinces on Viti Levu.

8. United General Party (UGP). The UGP sought to represent the interests of the 'general electors', that is to say that portion of the population who were neither Indo-Fijian nor indigenous Fijian, and who are predominantly the descendents of European and Chinese migrants.

In addition to these parties, a large number of smaller parties emerged in the lead-up to the elections. Moreover, a number of independent candidates stood for elected office.

However, despite the multiplicity of parties, in the 1999 general elections the primary contest was between two groupings of parties: a more formal SVT/NFP/UGP coalition; and a looser, FLP/FAP/PANU combination. Both groupings consisted of individual parties that presented themselves as 'mainstream', capable of providing leadership to their supporters within the indigenous Fijian and IndoFijian communities and capable of entering into 'deals' on behalf of their supporters. At the same time, both groupings collectively had a reasonable degree of internal discipline, and as such could be treated as 'unitary actors', able to produce a cohesive pre-election alliance with the capability to form a plausible government.

The SVT /NFP/UGP coalition consisted of what might be considered the 'mainstream' ethnic parties. The coalition was consolidated during the period of the constitutional review, when the SVT and the NFP, the bulk of the coalition, worked closely together, and was considerably strengthened after the passing of the Constitution Amendment Act in 1997. During the elections, both the leaders of the SVT and the NFP, Rabuka and Jai Ram Reddy respectively, were correctly projected as the principal driving force 
behind the revised constitution, having undertaken the principal negotiations, rallied the support of the elected members of the two ethnic groups for the constitutional settlement (Robertson, this volume), received the endorsement of the Great Council of Chiefs, and ensured the implementation of the necessary provisions of the new Constitution in the run up to the 1999 general elections. As such the two leaders were able to enter into pre-electoral agreements of importance to the two main ethnic groups in Fiji. From such a perspective, it is not surprising that ethnic unity became a principal theme of their campaigns and a key means by which they sought to mobilise political support. Economic issues, on which the parties largely agreed, such as the need to push ahead with policies of structural adjustment, were relegated to a secondary status.

This contrasted with the FLP/FAP/PANU combination. The principal source of strength for this combination was the FLP, which had a pre-existing support base amongst Indo-Fijian sugarcane farmers and a narrower, but nonetheless significant, multiethnic support base amongst the trade unions. By way of contrast, the FAP's appeal was more regionally specific and was also perhaps apparent amongst a comparatively small segment of the liberal indigenous Fijian middle class (Ratuva, this volume). Similarly, the PANU was also a regional party. Thus, within this combination, and with the exception of the FLP, the other parties were less unitary, with weaker leadership and less unified platforms. This combination thus reflected the pattern of a looser, 'post-election' arrangement.

The FLP/FAP/PANU combination concentrated its campaign upon economic and social issues, including low rates of economic growth, declining investment rates, and high unemployment (Sepehri and Akram-Lodhi, this volume). The FLP's emphasis on these issues was understandable, given both its origins and its support base. At the same time, both the PANU and the FAP also identified with these issues because economic stagnation and the impact of unemployment are, in Fiji, experienced more intensely in the urban areas and on Viti Levu, both of which served as the principal geographical base of support of the two parties. Notwithstanding a common overall agenda, there were clear policy differences between the FAP, the PANU and the FLP. The FLP demonstrated a consistently hostile attitude to policies of structural adjustment, while the FAP and the PANU were more sympathetic to the need to continue the structural 
adjustment process even as they sought to reassure those that had lost out in the process that they would have recourse to social safety nets. However, despite these differences, in their emphasis on economic issues the second combination could be said to have been more class based, although it must be admitted that organisationally it remained a combination of three largely ethnically based parties.

The 1999 general elections thus displayed a strong undercurrent of the tensions caused by alternative forms of political mobilisation. On the one hand there were two primarily ethnic parties, the SVT and the NFP, which had nonetheless been able to negotiate a new constitutional arrangement. On the other hand there was a more class based political momentum, which could be associated with the FLP-led combination, even though the organisational basis for this form of mobilisation was largely based upon ethnic groups. As will be seen, the impact of these factors will have been felt in the outcome of the election.

Serious concerns were raised in advance of the elections about the capacity of the electoral authorities to administer elections under such a complex electoral system. Some doubts were also aired about the fairness of elections given the complexity of the AV system. It is however possible to assess the fairness of elections, using a set of agreed guidelines. These guidelines include: the independence of the electoral authorities; the respect for the law by the election administrators; the transparency and accuracy of the administration of the elections; and the 'voter-friendly' nature of the administration of the election (Institute for Democracy and Electoral Assistance 1998). With the exception of the final point, both the peoples of Fiji and independent observers have generally regarded the 1999 general elections as having fulfilled these guidelines. Thus, the result has been seen as being by and large legitimate, and not capable of being challenged.

\section{Results in reserved seats}

As agreed by the JPSC and embedded within the 1997 Constitution, in the 1999 general elections there were 23 parliamentary seats reserved for indigenous Fijians ('Fijian communal seats'), 19 parliamentary seats reserved for Indo-Fijians ('Indian communal seats'), 3 parliamentary seats reserved for general electors, and 1 parliamentary seat reserved for the Rotuman community. 
Considering first those seats reserved for the indigenous Fijian community, overall the SVT received 38 per cent of the first preferences, while the FAP and VLV both received 18 per cent of the first preferences. The PANU and the NVTLP received 10 and 9 per cent of first preferences respectively. However, as a consequence of the $\mathrm{AV}$ electoral system, the distribution of first preferences and the distribution of parliamentary seats were very different. Table 3.1 demonstrates the distribution of parliamentary seats amongst those parties that contested seats reserved for the indigenous Fijian community. As is demonstrated in Table 3.1, while the SVT received 38 per cent of the first preferences, this was only translated into 5 parliamentary seats, some 22 per cent of the total. The FAP, which received 18 per cent of the first preferences, won 9 parliamentary seats, some 39 per cent of the total, while the VLV, which also received 18 per cent of the first preferences won only 13 per cent of the parliamentary seats.

Turning to the seats reserved for other communities, amongst the Indo-Fijian community the FLP obtained 66 per cent of the first preferences, while the NFP received 32 per cent of the first preferences. Again however the distribution of first preferences was very different from the distribution of parliamentary seats: all 19 seats reserved for the Indo-Fijian community were won by FLP. Finally, the UGP won one of the 3 parliamentary seats reserved for the general electors; the other two seats reserved for the general electors as well as the seat reserved for the Rotuman community were won by independent candidates.

Examining the results for the reserved parliamentary seats three points in particular stand out. The first point was the overwhelming support for the FLP amongst the Indo-Fijian electorate, which, by winning a clear majority in all seats reserved for the Indo-Fijian

\section{Table 3.11999 election results for 'Fijian communal seats'}

$\begin{array}{lr}\text { SVT } & 5 \\ \text { VLV } & 3 \\ \text { FAP } & 9 \\ \text { Independent } & 1 \\ \text { PANU } & 4 \\ \text { NVTLP } & 1 \\ \text { Total number of seats } & 23\end{array}$


community, effectively wiped out the NFP. The success of the FLP can be attributed to its broad appeal amongst the Indo-Fijian community throughout the country: unlike 1987 and 1992, the FLP was successful in both rural and urban constituencies. Clearly, the effort to focus its policies upon the interests of smallholder Indo-Fijian farmers and urban working classes by articulating an anti-structural adjustment agenda worked. In a sense then although the use of reserved seats was expected to foster appeals to ethnic identity, in the case of the FLP voter choices may have been governed by factors other than ethnic identity alone.

The second point to stand out from the results for the reserved parliamentary seats was the extent to which provincial loyalties appeared to strongly affect voting outcomes within the indigenous Fijian community. The SVT's support was quite strong in Cakaudrove and Kadavu. Similarly, the PANU won all its reserved parliamentary seats in Ba. The FAP also won all of its reserved parliamentary seats on Viti Levu. Thus, no indigenous Fijian political party in the 1999 general election was able to attract a wide base of support across the rural and urban regions of Fiji; provincialism appeared to overwrite the ideological appeals of the different political parties. Again, although the use of reserved seats was expected to facilitate the use of ethnic identity as a tool of political mobilisation, in the case of the indigenous Fijian electorate voter choices appeared to be governed by factors other than ethnic identity alone. This in turn helps explain, to a degree, the collapse of the ruling SVT, which won only 5 of the 23 parliamentary seats reserved for the indigenous Fijian community.

The third point to stand out from the results for the reserved parliamentary seats is more speculative. It may be the case that the policies pursued by the SVT while in power, both in the field of economic development and in its support for the consociational settlement between Fiji's ethnic communities (Ghai, this volume), contributed to a strengthening of provincial loyalties and a weakening of the role played by ethnicity in political mobilisation. The policies of structural adjustment pursued by the SVT while in power have had geographically uneven effects both within and between Fiji's ethnic communities. Thus, different provinces are differentially positioned within the national political economy, which may have fostered a provincialism which has been simmering for a very long time and which to an extent may have been able to override appeals to ethnic unity. 
At the same time, both Cakaudrove and Kadavu, where the SVT won decisive victories, are largely populated by indigenous Fijians. In these provinces there is little interaction between the two main ethnic communities and while there was clear support for the SVT this may not have represented support for one of its key policy initiatives, the consociational settlement, because in these provinces the SVT was, perhaps simplistically, seen as the party of indigenous Fijians. By way of contrast, in the western provinces of Viti Levu the PANU and the FAP did well. These provinces are far more ethnically mixed and there is considerable economic, social and political interaction between the ethnic communities. In these regions, therefore, the electoral arrangement reached between the PANU and the FAP on the one hand and the FLP on the other hand was perhaps more acceptable to the indigenous Fijian electorate, in part because of an acceptance of the need for a consociational settlement. If such an argument were accurate, the acceptance of the need for a consociational settlement would in all likelihood have weakened the electoral usefulness of an appeal to ethnic identity. In order to assess the veracity of these speculations there is a need for further scrutiny. In order to do this it is necessary to assess the results of the 1999 election in the 25 open seats.

\section{Results in open seats}

The results for the 25 open parliamentary seats are summarised in Table 3.2. Table 3.2 demonstrates the dominance of the FLP in the electoral contest for the open parliamentary seats, winning 72 per cent of the seats. The SVT, the FLP's nearest rival in the contest for the open parliamentary seats, could only win 12 per cent of the seats.

The results presented in Table 3.2 have some bearing on understanding whether the $\mathrm{AV}$ electoral system was capable of promoting the broader objectives envisaged by the FCRC: namely, increased inter-ethnic cooperation between and within political parties. In only four of the open seats did the parties win on the first preference. Three of these seats were won by the FLP, while one was won by the SVT. In order to demonstrate then that the AV system encouraged inter-ethnic cooperation in the short term it would be necessary to show that parties engaged in electoral contests for the 21 open seats which were not won on the basis of first preferences were able to come to arrangements concerning the 'sharing' of preferences. 


\section{Table 3.21999 election results in the open seats}

$\begin{array}{lr}\text { FLP } & 18 \\ \text { SVT } & 3 \\ \text { FAP } & 1 \\ \text { Independent } & 1 \\ \text { NVTLP } & 1 \\ \text { UGP } & 1 \\ \text { Total number of seats } & 25\end{array}$

Note: ${ }^{1}$ This seat has been subject to a recount following an appeal to the High Court by the FAP candidate.

This in turn makes it necessary to think about the extent and type of cooperation between parties. In short, it becomes necessary to evaluate the strategies of Fiji's political parties during the 1999 elections.

A first step in evaluating the strategies of Fiji's political parties in the open seats is to evaluate the ethnic composition of the open seats. As has already been demonstrated in the reserved seats, the FLP's support amongst Indo-Fijians was overwhelming. This can be contrasted with the regional concentration of support for indigenous Fijian parties, and particularly the SVT, the PANU, the FAP and the VLV. Nonetheless, it is possible that while voter choice for the reserved seats may have been determined by factors other than ethnicity, for the open seats ethnicity may have remained the dominant logic governing voter choice. In order to gauge whether this was in fact the case it is necessary, as a first step, to assess the ethnic composition of the open seats that were contested.

The Constituency Boundaries Commission defined the boundaries of all seats, including the open seats. In defining the open seats the Commission had to take into regard geographical factors as well as the ethnic composition of the constituency. This was because in order for the open seats to work effectively under the $\mathrm{AV}$ system there was a need to ensure a reasonable ethnic mix in each of the open seats.

Despite this however in 14 open seats the proportion of the voting population attributable to one ethnic group exceeded 60 per cent. Of these 14 seats, in 8 the indigenous Fijian share of the voting population exceeded 60 per cent of the total voters. In these the SVT did well, winning three seats. At the other end of the spectrum, in 6 of the open seats the Indo-Fijian share of the voting population was in excess of 60 
per cent of the total voters. The FLP won all 6 of these seats, and indeed won 3 on the basis of first preferences. The AV system may thus have had a curious effect on these 14 open seats. Despite the fact that in the reserved seats voter choice may have been guided by factors other than ethnicity, in 14 of the open seats parties which focused on winning a large majority of the votes of the dominant ethnic community had an apparently reasonable chance of winning outright. These open seats may thus have witnessed voter choice being guided by ethnicity.

In the remaining 11 seats the share of the population between the two dominant ethnic communities was relatively more even: no community had more than 60 per cent of the electorate in any of these seats. It can be argued that the real contest in the 1999 general elections was in these 11 seats, because it was only in these seats that the allocation of preferences required that parties rooted in one ethnic community appeal to voters in other ethnic communities. The need to appeal to voters across the ethnic divide necessitated cooperation between parties, as envisaged by the FCRC, and led to pre-electoral arrangements between the political parties. Thus, as has already been noted, the SVT, the UGP and the NFP entered into a firm pre-election coalition. The FLP however operated somewhat differently. The FLP, the FAP and the PANU fielded candidates against each other in the open seats. Indeed, in several seats the competition between the FAP and the FLP candidates was particularly intense. The preferenceswapping deal arranged between the FLP, the FAP and the PANU was thus reserved for second preferences, in order to capitalise on the regional concentration of indigenous Fijian support for both the FAP and the PANU and more general Indo-Fijian support for the FLP. Working in this way not only denied the SVT/UGP/NFP candidates chances of gaining a majority on the first count, it also increased the FLP /FAP/PANU chances of winning on second and later counts. Overall then the FAP, the PANU and the FLP parties worked more realistically as a 'vote-pooling block' than did the SVT/NFP/UGP coalition.

In addition to the advantages derived from the preference sharing arrangement and a majority of Indo-Fijian support, the FLP is estimated to have won in excess of 10 per cent of the indigenous Fijian vote outright in at least 6 of the remaining open seats. Thus, the FLP was well positioned to win a majority of the open seats where the 
distribution of the population was relatively even between the two main ethnic communities. Given this, it is then not surprising that the FLP did very well in these seats. Overall, the FLP won 36

parliamentary seats out of a total of 71 .

Two further comments on the election results can be offered. The first recalls the point that the $\mathrm{AV}$ system was designed to promote increased cooperation between parties. Clearly, an examination of the results in the open seats shows that the type and level of cooperation between parties is crucial to understanding the outcome of the election. On this account then the AV system fulfilled its objective, albeit in ways which those who had designed the system probably did not envisage. The second comment concerns the overall outcome. Despite having misgivings about particular aspects of the Constitution, the SVT, the NFP, the FLP, the PANU and the FAP all support the broad parameters of the Constitution. Votes for these parties therefore may be taken to at least translate partially into support for the Constitution, and the 1999 elections can be considered to have been a national referendum on the Constitution. In this light, the mandate received in support of the 1997 Constitution is overwhelming by any account.

\section{Representation in cabinet}

The number of seats won by the FLP gave it the ability to form a government on its own. However, the Constitution required that the FLP invite other parties to participate in the executive. Table 3.3 therefore presents the overall distribution of parliamentary seats by party, together with the resulting entitlement to cabinet seats as set out in the 1997 Constitution, as well as the proportion of cabinet seats actually held by individual parties.

Particularly through its provisions for multiparty government the 1997 Constitution seeks to institutionalise power sharing amongst Fiji's ethnic communities. Broadly, the concept of power sharing has been operationalised in the aftermath of the elections, albeit through some difficult negotiations and in a manner that is probably somewhat different from that envisaged by those who framed the Constitution. Initially, power-sharing negotiations focused on the FLP's proposed candidate for Prime Minister, its leader Mahendra Chaudhry. At first the FAP and the PANU refused to accept an Indo-Fijian as the Prime Ministerial candidate. Following the negotiation process, the FAP and 
the PANU conceded the designation of an Indo-Fijian as Prime Minister in exchange for being over-represented in the Cabinet. This outcome was designed to allay fears about an Indo-Fijian dominated govermment. It was also a reward for the preference sharing arrangements that gave the FLP victory in several open seats.

In line with constitutional obligations, the Prime Minister-designate invited the SVT to become a part of the cabinet. Initially, the SVT responded to this invitation favourably. However, the SVT also indicated that its participation was to be tied to a number of conditions, over which the Prime Minister was not prepared to negotiate (Fiji Times, 20-29 May 1999). As a consequence, the SVT is not participating in the cabinet even though it has cleared the threshold for cabinet representation.

A power-sharing executive is likely to act as a safety valve against the outright domination of government by a single ethnic group. Indeed, this outcome is an implicit objective of the 1997 Constitution. However, power sharing at this level may also act in another, possibly more important, manner. Power sharing may prevent a single party from dominating the policy agenda. As a consequence, while the FLP went into the elections on a platform of social and economic justice, it is possible that it will not be able to implement the full range of its social and economic agenda, given the need to maintain the support of other political parties in the executive arm of government. Granted, Chapter Five of the 1997 Constitution directs the state to make provisions for programs designed 'to achieve for all groups or categories of persons who are disadvantaged effective equality of

\section{Table 3.3 Party representation in Cabinet after the 1999 elections}

$\begin{array}{lccr}\text { Party } & \begin{array}{c}\text { Total seats in } \\ \text { Parliament }\end{array} & \begin{array}{c}\text { Per cent } \\ \text { entitlement to } \\ \text { Cabinet seats }\end{array} & \begin{array}{r}\text { Actual per } \\ \text { Cabinet sear } \\ \text { share of } 22\end{array} \\ \text { FLP } & 36 & 50 & 59 \\ \text { FAP } & 10 & 14 & 18 \\ \text { SVT } & 8 & 11 & 0 \\ \text { VLV } & 3 & \mathrm{~B} / \mathrm{t} & 9 \\ \text { PANU } & 4 & \mathrm{~B} / \mathrm{t} & 9 \\ \text { UGP } & 2 & \mathrm{~B} / \mathrm{t} & 0 \\ \text { NVTLP } & 2 & \mathrm{~B} / \mathrm{t} & 0 \\ \text { Independent and Rotuma } & 5 & \mathrm{~B} / \mathrm{t} & 5\end{array}$

Note: $B / t$ - Below threshold 
access to education, land, housing, and participation in commerce' (Ghai, this volume). Although this commitment is 'non-justiciable', were it to be enforced, the neoliberal direction of economic policy that came to be associated with the SVT over the past decade would certainly come into question. Despite this however the reality of power sharing may well result in the FLP's aversion to orthodox policies of structural adjustment being diluted to accommodate the more pro-liberalisation orientation of its partners in Cabinet, such as the VLV and the FAP.

\section{Reflections on the AV system}

Many commentaries in the local dailies and responses by political leaders following the swearing-in of the Cabinet have continued to raise concerns about an Indo-Fijian dominated government. After all, it was the emergence of Indo-Fijian power in the cabinet that led to the coups in 1987. Although public opposition is considerably more muted than that which was observed following the FLP-led victory in 1987, it remains a cause for concern. Many appear to blame the AV system as the primary cause of the downfall of the SVT government and the cause of 'disunity' amongst indigenous Fijians. Some further remarks about the operation of this system of voting are therefore in order.

The AV system used in the 1999 general elections was introduced in order to generate effective government and effective political parties capable of serving national constituencies. At the same time, it was argued that the AV system provided the best incentives for cooperation between ethnically based political parties (FCRC 1996). Moreover, to reinforce the pursuit of inter-ethnic cooperation the JPSC tried to back up the strengths of the AV system by introducing constitutional provisions for multiparty government. However, the AV system did not work as it was thought it would.

As has already been demonstrated, the political parties that contested the 1999 general elections attempted to maximise their strength by trying to win reserved seats. However, in trying to win such seats, while all the main parties relied upon obtaining support from within particular ethnic communities, those that were successful may not have used an appeal to ethnic identity as the means of obtaining that support. Rather, they may have used other forms of identity as the basis of electoral mobilisation. Thus, indigenous Fijian 
parties relied heavily upon provincial loyalties, while the FLP relied heavily upon its support base amongst Indo-Fijian farmers and workers. The possible weakness of ethnic politics in the reserved seats was not expected of the AV system.

Paradoxically, in open seats where one ethnic community dominated the voter population there was probably a wider implicit reliance upon ethnic identity as a central part of political mobilisation. This is probably true even as regards the most multiethnic of the major parties, the FLP. Granted, the FLP's capacity to skilfully deploy its policy platform meant that its appeal to the Indo-Fijian vote in such seats did not have to be couched in ethnic terms. Nonetheless, even the FLP did not have to try and increase its support amongst the indigenous Fijian community in these seats; it could rely upon its support amongst Indo-Fijian farmers and workers to win seats. Such an outcome was not what the FCRC had expected of the AV system. Moreover, such an outcome is obviously not in the long term interest of a class-based party such as the FLP.

Finally, in those open seats where no one community dominated the voter population, cooperation between parties was fostered in the form of efforts to share preferences. Thus, the AV system did indeed promote increased cooperation between parties. However, the type of cooperation between parties is also important to consider. The SVT and the NFP, the two principal actors in the constitutional review process, entered, along with the UGP, into a formal coalition. The voters rejected this. The FLP, on the other hand, entered into an agreement with the PANU and the FAP regarding second preferences, and were rewarded handsomely. It can thus be cautiously argued that when given appropriate alliance structures and incentives, communities in Fiji may be willing to vote for parties other than those rooted in their own ethnic group.

However, the depth of the commitment to cross-community politics engendered amongst ordinary voters by party strategies designed to maximise first and second preferences can be questioned when the parties are themselves largely ethnically based. The 1999 general elections illustrate the point. Both the groupings were groupings of largely ethnically based political parties. To that end, the individual parties of these groupings organised their own campaigns. As a consequence, interaction between workers and supporters of different ethnically based political parties and indeed between voters of different 
ethnic groups was limited. In this light, it is not surprising that during the elections there was little change in the mindset of voters: obviously, while the AV system did promote greater cooperation between parties, this occurred at the level of the élites who controlled the parties. That there was little change in the mindset of voters can be illustrated by the pattern of voting. Under the electoral procedures, voters could either indicate the political party of their choice or they could register their own individual preferences amongst the candidates of those parties. In most constituencies, less than 5 per cent of voters exercised their individual preferences, which would have demonstrated a greater willingness to engage in the messy realities of cross-community politics. Thus, the AV system may not have helped consolidate openness to multiethnic politics amongst ordinary party workers, supporters and voters. As a consequence, the $\mathrm{AV}$ system was not really able to break down the ethnicisation of politics in Fiji. Indeed, by fostering cooperation only amongst élites it may well be the case that the AV system harms the prospects for cross-community, ideology-based parties.

In addition to not working as those who introduced it thought it would, the AV has had a clearly unfavourable impact upon the principle of proportionality in parliamentary representation. This is obviously demonstrated by the parliamentary representation of the SVT and the NFP. The SVT received 38 per cent of first preferences from within the indigenous Fijian community. This translated into only 11 per cent of overall seats in the House of Representatives. The NFP received 32 per cent of Indo-Fijian first preferences. This translated into no parliamentary seats. It is ironic that both the SVT and the NFP, which actively opposed proportional systems of parliamentary representation during the review of the constitution, would have been better represented in parliament under proportional representation. At the same time, the pooling of preferences which initially went to smaller, more independent parties and candidates in favour of one of the constituent parts of one of the larger party groupings may contribute to a loss of confidence in parliamentary democracy. Certainly, the AV system has severely weakened the parliamentary representation of the more extreme ethnic nationalist parties such as the NVTLP, and while a first reaction to such an outcome might be to welcome it, it is also necessary to be aware of potentially adverse consequences in the longer term should more extreme parties become disenfranchised from parliamentary representation as a consequence of the $\mathrm{AV}$ system. 


\section{Conclusion: confronting the present and the future}

Fiji's 1999 general elections were a national referendum on the 1997 Constitution. Given that the SVT, the NFP, the FLP, the FAP and the PANU all supported-albeit with some reservations—the 1997 Constitution, the mandate that it has received from the peoples of Fiji is overwhelming. However, despite this mandate, and despite the clear objectives of the Constitution in seeking to promote multiethnic politics in Fiji, it is clear that significant tensions remain between those who would use ethnicity as a primary means of political mobilisation and those who would use class as a primary means of political mobilisation. While the AV system has been able to foster cooperation amongst the political parties, and while multiparty government may reinforce this cooperation, the $\mathrm{AV}$ system has not been able to expunge the recourse to ethnicity as a tool of political mobilisation. It has possibly permitted a 'de-ethnicisation' of politics in reserved seats. However, it is indeed ironic that under the AV system the use of ethnicity may have been reinforced in those seats specifically designed to foster the emergence of a multiethnic politics: the open seats.

Moreover, where it has fostered cross-community cooperation, this has been amongst élites; it has not occurred amongst people. In this light, two suggestions emerge. The first is that Fiji would do well to critically reassess the suitability of AV system. Electoral systems which respect the proportionality of parliamentary representation are also capable of breaking down inter-ethnic boundaries, and perhaps these should be considered anew in light of the outcome of the 1999 general elections. The second is that the ratio of open to reserved seats must be re-examined and possibly reversed if Fiji is to move decisively towards a less ethnically based system of politics.

Clearly, as is evident in the other contributions to this volume, the tension between the use of ethnicity and the use of class as primary means of political mobilisation will continue to define the parameters of Fiji's politics. In this light, it is significant that the main challenges that any Fiji government will confront over the next decade are likely to emerge from factors associated with economic globalisation. It is unclear whether a consociational arrangement that may work to consolidate and indeed reify contested categories of ethnicity favours or undermines the capability of national governments to negotiate in an increasingly open, unforgiving and undiscriminating international environment. 
What is of a more immediate concern to the peoples of Fiji, however, is the level of commitment of the new government to the implementation and operation of the new Constitution. To a large extent it was the leaders of the NFP and the SVT who were able to negotiate a constitutional settlement, rally the support of the elected members of the two ethnic groupings for the constitutional 'deal', receive the endorsement of the Great Council of Chiefs, and ensure the implementation of the electoral provisions of the Constitution. The situation has now changed. Following the elections, the mantle of political leadership has passed on to leaders whose parties were less central to the negotiation of the Constitution. It remains to be seen whether the new government will accord a similar degree of importance to the implementation of all the provisions of the Constitution. It also remains to be seen whether the new government is committed to promoting the consensus amongst Fiji's main political parties regarding social and economic policy, which is implicit in the constitutional provisions regarding the formation of the executive. The extent of the commitment to policy consensus will be seen most prominently in the attention which is paid by the new government to indigenous Fijian rights and interests. Indeed, it is possible that the FLP's electoral commitment to delivering an ambitious social package may collide with the commitment to enhancing indigenous Fijian rights and interests that is a core pillar upon which the Constitution rests. Were such a collision to occur, it would undermine the potential that the FLP-led government has to radically transform Fiji's economy and its politics. Fiji's politics have entered a new era, and what the future may hold has yet to unfold.

\section{Endnote}

1. This chapter is a substantially revised version of Prasad (1999). 
This text is taken from Confronting Fiji Futures, edited by A. Haroon Akram-Lodhi, published 2016 by ANU eView, The Australian National University, Canberra, Australia. 